\title{
Aktivitas Enzim Pencernaan Amilase dan Protease Juvenil Abalon (Haliotis asinina) yang Dipelihara pada Salinitas Berbeda
}

[Digestive Enzyme Activity of Amylase and Protease in Juvenil Abalone (Haliotis asinina) Reared in Different Salinity]

\author{
Siti Aisyah Saridu ${ }^{*}$, Sutrisno Anggoro², Jusup Suprijanto², Irwan Junaedi Effendy ${ }^{3}$ \\ ${ }^{1}$ Program Studi Teknik Budidaya Perikanan, Politeknik Kelautan dan Perikanan Bone, Kabupaten Bone, \\ Sulawesi Selatan, Indonesia \\ ${ }^{2}$ Program Studi Manajemen Sumberdaya Pantai, Fakultas Perikanan dan Ilmu Kelautan, Universitas \\ Diponegoro, Semarang, Jawa Tengah, Indonesia \\ ${ }^{3}$ Program Studi Budidaya perairan, Fakultas Perikanan dan Ilmu Kelautan, Universitas Halu Oleo, Kendari, \\ Sulawesi Tenggara, Indonesia \\ *Email korespondensi: aisyahsaridu@gmail.com
}

\begin{abstract}
Abstrak
Salinitas merupakan salah satu parameter kualitas air yang mempengaruhi kehidupan hewan akuatik, termasuk molluska laut. Tujuan penelitian ini adalah untuk mengetahui aktivitas enzim pencernaan amilase dan protease juvenil $H$. asinina yang dipelihara pada salinitas berbeda. Penelitian dilakukan menggunakan rancangan acak kelompok. Hewan uji dibagi berdasarkan kelompok ukuran panjang cangkang, yaitu 2,0-2,5 cm, 3,0-3,5 cm dan 4,0-4,5 $\mathrm{cm}$ dan dipelihara pada salinitas berbeda yaitu 26\%o, 29\%o, 32\%o dan 35\%o selama 30 hari. Selama masa pemeliharaan, hewan uji diberikan pakan alami Gracilaria verrucosa. Pengukuran aktivitas enzim pencernaan dilakukan pada hepatopankreas dan organ viscera. Hasil penelitian menunjukkan bahwa salinitas media berbeda berpengaruh nyata terhadap aktivitas amilase dan protease $(\mathrm{P}<0,05)$. Aktivitas amilase pada salinitas $26 \%$, 29\%o, 32\%o dan $35 \%$ berturut-turut yaitu $1,1387 \pm 0,2158 \mathrm{U} / \mathrm{mg}$ protein, $1,0908 \pm 0,3531 \mathrm{U} / \mathrm{mg}$ protein, $0,7595 \pm 0,1044 \mathrm{U} / \mathrm{mg}$ protein dan $0,7137 \pm 0,2014 \mathrm{U} / \mathrm{mg}$ protein. Aktivitas protease juvenil yang dipelihara pada salinitas $26 \%$, 29\%o, 32\%o dan 35\%o berturut-turut yaitu $0.0031 \pm 0.0045$ $\mathrm{U} / \mathrm{mg}$ protein, $0.0177 \pm 0.0103 \mathrm{U} / \mathrm{mg}$ protein, $0.0167 \pm 0.0118 \mathrm{U} / \mathrm{mg}$ protein dan $0.0239 \pm 0.0023 \mathrm{U} / \mathrm{mg}$ protein. Berdasarkan hasil penelitian, $H$. asinina sebaiknya dipelihara pada salinitas $>29 \%$ karena aktivitas protease yang sangat rendah dapat menurunkan kecernaan protein sehingga menghambat pertumbuhan.
\end{abstract}

Kata Kunci: juvenile H. asinina, aktivitas amilase, aktivitas protease, salinitas

\begin{abstract}
Salinity is one of the water quality parameters that affect the life of aquatic animals, including marine mollusks. The purpose of this study was to determine the value of the digestive enzyme activity of amylase and protease in abalone juvenile $H$. asinina reared at different salinities. The study was conducted using a randomized block design. Juveniles were grouped based on shell length namely $2.0-2.5 \mathrm{~cm}, 3.0-3.5 \mathrm{~cm}$ and $4.0-4.5 \mathrm{~cm}$ and maintained at salinity of 26\%, 29\%o, 32\%o and 35\%o for 30 days. Juveniles were fed with Gracilaria verrucosa. Digestive enzyme activity analysis was carried out on the hepatopancreas and abalone viscera. The results showed that different media salinity had a significant effect on amylase and protease activity $(\mathrm{P}<0.05)$. Amylase activity in juveniles reared at salinity of $26 \%$, $29 \%$, 32\%o dan 35\%o was $1.1387 \pm 0.2158 \mathrm{U} / \mathrm{mg}$ protein, $1.0908 \pm 0.3531 \mathrm{U} / \mathrm{mg}$ protein, $0.7595 \pm 0.1044 \mathrm{U} / \mathrm{mg}$ protein, and $0.7137 \pm 0,2014 \mathrm{U} / \mathrm{mg}$ protein, respectively. Protease activity in juveniles at salinity of $26 \%$, 29\%o, 32\%o dan 35\% was $0.0031 \pm 0.0045 \mathrm{U} / \mathrm{mg}$
\end{abstract}


Media Akuatika : Jurnal Ilmiah Jurusan Budidaya Perairan. 2021. 6(3): 135-143.

protein, $0.0177 \pm 0.0103 \mathrm{U} / \mathrm{mg}$ protein, $0.0167 \pm 0.0118 \mathrm{U} / \mathrm{mg}$ protein and $0.0239 \pm 0.0023$ $\mathrm{U} / \mathrm{mg}$ protein, respectively. Based on the, $H$. asinina should be maintained at salinity $>29 \%$ o due to extremely low digestive protease which can reduce protein digestibility thereby inhibiting growth.

Keyword: juvenile H. asinina, activity of amylase, activity of protease, salinity

\section{PENDAHULUAN}

Keberhasilan kegiatan budidaya hewan akuatik, termasuk abalone (Haliotis sp.) sangat dipengaruhi oleh kualitas air sebagai media pemeliharaan, karena seluruh aktifitas kehidupan hewan akuatik, seperti bernafas, eskresi, mencari makan, tumbuh, reproduksi serta pengaturan keseimbangan osmotik dilakukan di dalam air (Zweig, 1999; Burke et al., 2001; Bhatnagar dan Devi, 2013). Salah satu parameter kualitas air dalam budidaya akuatik yang mempengaruhi kehidupan hewan akuatik, termasuk molluska laut, adalah salinitas (Cheng et al., 2002). Studi sebelumnya menyatakan bahwa salinitas memiliki keterkaitan langsung dengan pengaturan osmotik, mempengaruhi tingkat pembelanjaan energi, sintasan, kesehatan, nafsu makan, kecernaan serta penyerapan nutrisi (Anggoro, 1992; Anggoro, 2000; Moutou et al., 2004; Tsuzuki et al., 2007; Magnussen et al., 2008; Romano, 2010).

Beberapa studi telah dilakukan untuk menentukan salinitas optimal pemeliharaan beberapa spesies abalon. Moustakas et al. (2004) menyatakan bahwa pengaruh dalinitas dapat berbeda antara spesies dan fase perkembangan sehingga level salinitas optimal dalam pemeliharaan abalon dapat berbeda antar spesies. Hasil studi menunjukkan salinitas untuk pertumbuhan optimal abalone jenis $H$. discus hannai berkisar pada $25 \%-44 \%$, abalon jenis $H$. rufescens pada $32 \%$, $H$. tuberculata pada $34 \%, H$. laevigata pada 34\%, $H$. diversicolor supertexta and $H$. fulgens pada $35 \%$, dan $H$. varia 32\%. Selain itu juga diperoleh bahwa energi pertumbuhan dan metabolisme $H$. diversicolor aqualitis berada pada nilai tertinggi pada salinitas 37\% (Xizhu, 2004). Sementara itu, Chaitanawistuti et al. (2012) menyatakan bahwa kondisi optimal pemeliharaan juvenil $H$. asinina adalah pada salinitas 31\%o-33\%o.

Keberhasilan pemeliharaan abalone dapat ditunjukkan dengan pemanfaatan pakan yang optimal dalam penyediaan energi untuk pertumbuhan dan sintasan yang tinggi. Sementara itu, hasil studi menunjukkan bahwa juvenil abalon $H$. squamata yang dipelihara pada salinitas berbeda memiliki nilai kecernaan yang berbeda signifikan (Wahyu et al., 2014). Perbedaan nilai kecernaan tersebut diduga memiliki keterkaitan dengan kerja aktivitas enzim yang dipengaruhi oleh perubahan salinitas media. Beberapa hasil penelitian menunjukan bahwa salinitas mempengaruhi aktivitas enzim pencernaan, termasuk amilase, selulase, pepsin, trypsin, lipase, chymotrypsin dan protease beberapa jenis hewan akuatik (Moutou et al., 2004; Tsuzuki et al., 2007; Wang et al., 2013). Enzim perncernaan merupakan substansi kimia dalam sistem pencernaan yang berfungsi untuk hidrolisis nutrien sehingga menjadi bentuk sederhana yang dapat diserap oleh sel-sel tubuh. Implikasi dari aktivitas enzim pencernaan yang berbeda adalah nilai kecernaan pakan yang juga akan berbeda (Moutou et al., 2004).

Studi sebelumnya yang menyelidiki pengaruh salinitas terhadap aktivitas enzim protease pada Sparus aurata menemukan bahwa aktivitas enzim protease dipengaruhi oleh salinitas dimana aktivitas total acidprotease di perut dan tripsin di usus lebih tinggi pada salinitas rendah dibandingkan pada salinitas yang lebih tinggi (Moutou et 
al., 2004). Tsuzuki et al. (2007) melakukan observasi mengenai pengaruh salinitas terhadap aktivitas enzim alkalin proteinase pada Centropomus paralellus dan diperoleh bahwa aktivitas enzim tersebut berbeda nyata pada perlakuan salinitas berbeda meskipun ikan tersebut bersifat eurihalin. Sementara itu, informasi terkait pengaruh salinitas terhadap aktivitas enzim pencernaan abalone $H$. asinina masih sangat terbatas. Oleh karena itu, penelitian ini bertujuan untuk mengetahui nilai aktivitas enzim pencernaan amilase dan protease juvenil $H$. asinina yang dipelihara pada salinitas berbeda. Informasi yang diperoleh dari penelitian ini dapat menjadi salah satu pertimbangan dalam pemilihan lokasi untuk budidaya abalon, khususnya abalon jenis $H$. asinina.

\section{BAHAN DAN METODE}

Hewan uji yang digunakan adalah juvenil $H$. asinina hasil pembesaran hatchery abalon di Desa Tapulaga Kec. Soropia Kab. Konawe Sulawesi Tenggara dengan ukuran 2,0-4,5 cm. Pemeliharaan juvenil abalon dilakukan dengan menggunakan kontainer plastik bening berbentuk silinder volume 16 yang diisi air media pemeliharaan sebanyak 15 1/kontainer. Hewan uji dibagi berdasarkan kelompok ukuran panjang cangkang pada tiga kelompok ukuran, yaitu $2,0-2,5 \mathrm{~cm}$, $3,0-3,5 \mathrm{~cm}$ dan $4,0-4,5 \mathrm{~cm}$ yang dipelihara pada salinitas berbeda yaitu 26\%o, 29\%o, $32 \%$ dan 35\%. Sebelum dimasukkan ke dalam wadah pemeliharaan, hewan uji sebanyak 8 individu per wadah, dipuasakan terlebih dahulu selama 24 jam. Pemeliharaan dilakukan tanpa sistem air mengalir (flow trough) dan dilakukan pergantian air $100 \%$ setiap $1 \times 24$ jam untuk mempertahankan kualitas air media pemeliharaan. Pemeliharaan hewan uji dilakukan selama 30 hari. Selama masa pemeliharaan, hewan uji diberi pakan rumput laut jenis Gracilaria sp. dengan jumlah $30 \%$ dari total bobot tubuh abalon dalam satu unit percobaan. Pemberian pakan dilakukan setiap 1x24 jam setelah dilakukan pergantian air.

Analisis aktivitas enzim dilakukan di Laboratorium Nutrisi Ikan FPIK IPB. Pengamatan aktivitas enzim pencernaan dilakukan pada hepatopankreas dan organ viscera abalon. Aktivitas amilase diukur menggunakan larutan pati $1 \%$ sebagai substrat dalam buffer natrium fosfat 20 $\mathrm{mM}, \mathrm{pH}$ 6,9, dan mengandung $\mathrm{NaCl}$ 6,0 $\mathrm{mM}$. Sebanyak $0,5 \mathrm{~mL}$ larutan substrat ditambahkan ke dalam 0,5 $\mathrm{mL}$ sampel ekstrak enzim kasar, dan kemudian diinkubasi selama 3 menit pada temperatur $95^{\circ} \mathrm{C}$. Reaksi dihentikan dengan penambahan asam dinitrosalisilat (DNS) sebanyak $0,5 \mathrm{ml}$, lalu diinkubasi kembali dalam air mendidih selama 5 menit. Selanjutnya dilakukan pembacaan nilai absorbansi dengan spektrofotometer pada panjang gelombang $540 \mathrm{~nm}$. Jumlah maltosa yang dilepas ditentukan dari kurva standar. Satu unit aktifitas enzim didefiniskan sebagai jumlah amilase yang diperlukan untuk menghidrolisis $1 \mu \mathrm{mol}$ maltosa per menit atau substrat $/ \mathrm{min} / \mathrm{mg}$ protein (U/mg protein).

Analisis aktivitas protease dilakukan dengan menyiapkan tiga tabung untuk tabung sampel, standar dan blanko. Pada ketiga tabung kemudian ditambahkan $1 \mathrm{ml}$ buffer fosfat $0,05 \mathrm{M} \mathrm{pH} 7$ dan substrat kasein $20 \mathrm{mg} / \mathrm{ml}$ sebanyak $1 \mathrm{ml}$. Pada masing-masing tabung kemudian ditambahkan 0,2 ml ekstrak enzim pada tabung sampel, 0,2 $\mathrm{ml}$ tirosin pada tabung standar, dan $0,2 \mathrm{ml}$ pada tabung blanko. Setelah itu, ketiga tabung diinkubasi pada temperatur $37^{\circ} \mathrm{C}$ selama 10 menit. Pada masing-masing tabung kemudian dimasukan $2 \mathrm{ml}$ TCA dan $0,2 \mathrm{ml} \mathrm{CaCl}_{2}$, dan akuades juga ditambahkan hanya pada tabung sampel sebanyak 0,2 ml. Setelah itu, ketiga tabung diinkubasi pada temperatur 37oC selama 10 menit dan kemudian disentrifugasi pada $3500 \mathrm{rpm}$ selama 10 menit. Pada masing-masing 1,5 $\mathrm{ml}$ supernatan yang diperoleh dari ketiga 
tabung kemudian ditambahkan $5 \mathrm{ml}$ $\mathrm{Na}_{2} \mathrm{CO}_{3}$ dan $1 \mathrm{ml}$ larutan pereaksi folin. Kemudian dilakukan inkubasi selama 20 menit pada temperatur $37^{\circ} \mathrm{C}$, lalu diukur absorbansinya dengan spektrofotometer pada panjang gelombang $578 \mathrm{~nm}$. Data hasil penelitian yang diperoleh dianalisis secara statistik menggunakan uji ANOVA. Jika terdapat perbedaan pengaruh perlakuan, maka dilakukan uji lanjut BNT. Data diolah menggunakan perangkat IBM SPSS 21.

\section{HASIL}

Hasil pengamatan terhadap aktivitas amilase pada organ viscera juvenil abalone yang diukur setelah masa pemeliharaan 30 hari disajikan pada Gambar 1 dan Gambar 2. Aktivitas amilase tertinggi diperoleh pada juvenil yang dipelihara pada salinitas $26 \% \quad(1,1387 \pm 0,2158 \mathrm{U} / \mathrm{mg}$ protein $)$, diikuti oleh juvenil pada media bersalinitas 29\% $(1,0908 \pm 0,3531 \mathrm{U} / \mathrm{mg}$ protein), 32\%o
$(0,7595 \pm 0,1044 \quad \mathrm{U} / \mathrm{mg}$ protein) dan aktivitas terendah pada salinitas $35 \%$ o $(0,7137 \pm 0,2014 \mathrm{U} / \mathrm{mg}$ protein $)$. Hasil analisis ragam menunjukkan bahwa perlakuan salinitas berbeda berpengaruh nyata terhadap aktivitas amilase juvenil abalon $H$. asinina $(\mathrm{P}<0,05)$.

Berbeda dengan enzim amilase, aktivitas protease tertinggi diperoleh dari juvenil abalon yang dipelihara pada media bersalinitas $35 \%$ o $\quad(0,0239 \pm 0,0023 \mathrm{U} / \mathrm{mg}$ protein), diikuti oleh juvenil yang pada salinitas $\quad 29 \%$ o $\quad(0,0177 \pm 0,0103 \quad \mathrm{U} / \mathrm{mg}$ protein), salinitas 32\%o $(0,0167 \pm 0,0118$ $\mathrm{U} / \mathrm{mg}$ protein) dan yang terendah pada salinitas $26 \%$ o $\quad(0,0031 \pm 0,0045 \quad \mathrm{U} / \mathrm{mg}$ protein). Hasil analisis ragam menunjukkan bahwa perlakuan perbedaan salinitas memberikan pengaruh yang signifikan terhadap aktivitas protease juvenil abalon H. asinina $(\mathrm{P}<0,05)$.

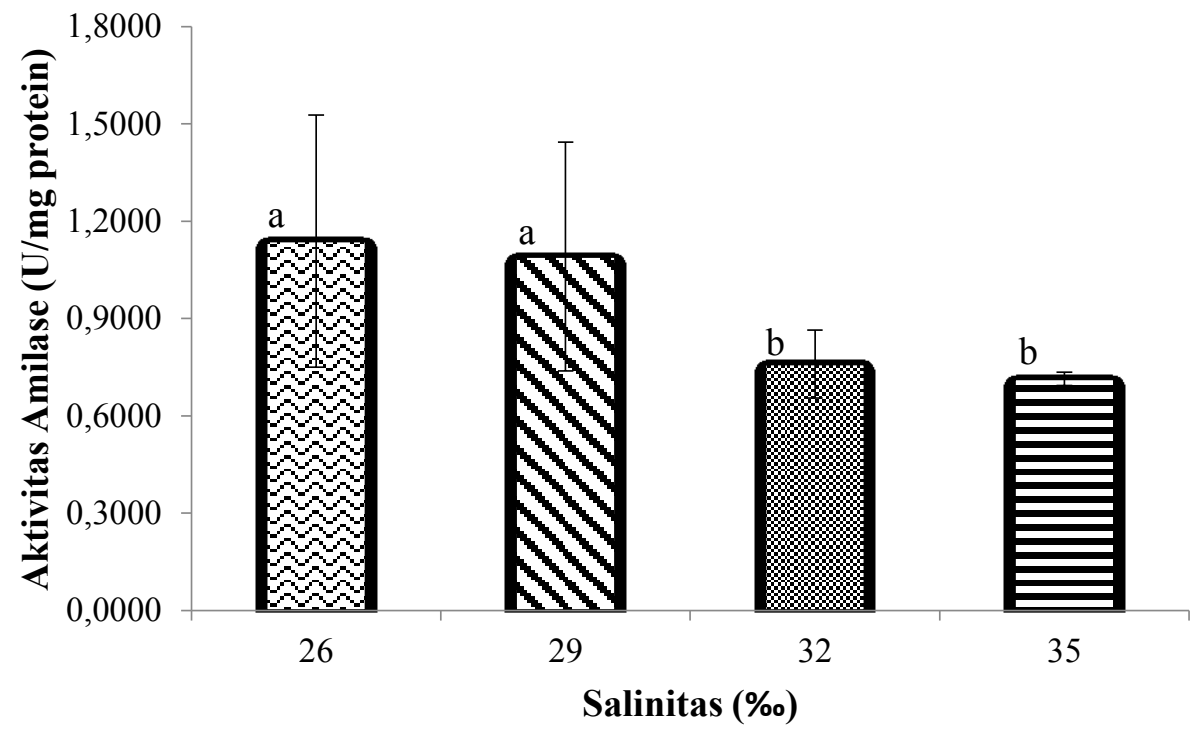

Gambar 1. Aktivitas amilase juvenil abalone H. asinina pada salinitas media berbeda. ${ }^{\mathrm{a}, \mathrm{b}}$ superscript yang berbeda menunjukkan perbedaan signifikan pada taraf $\alpha=0,05$. 


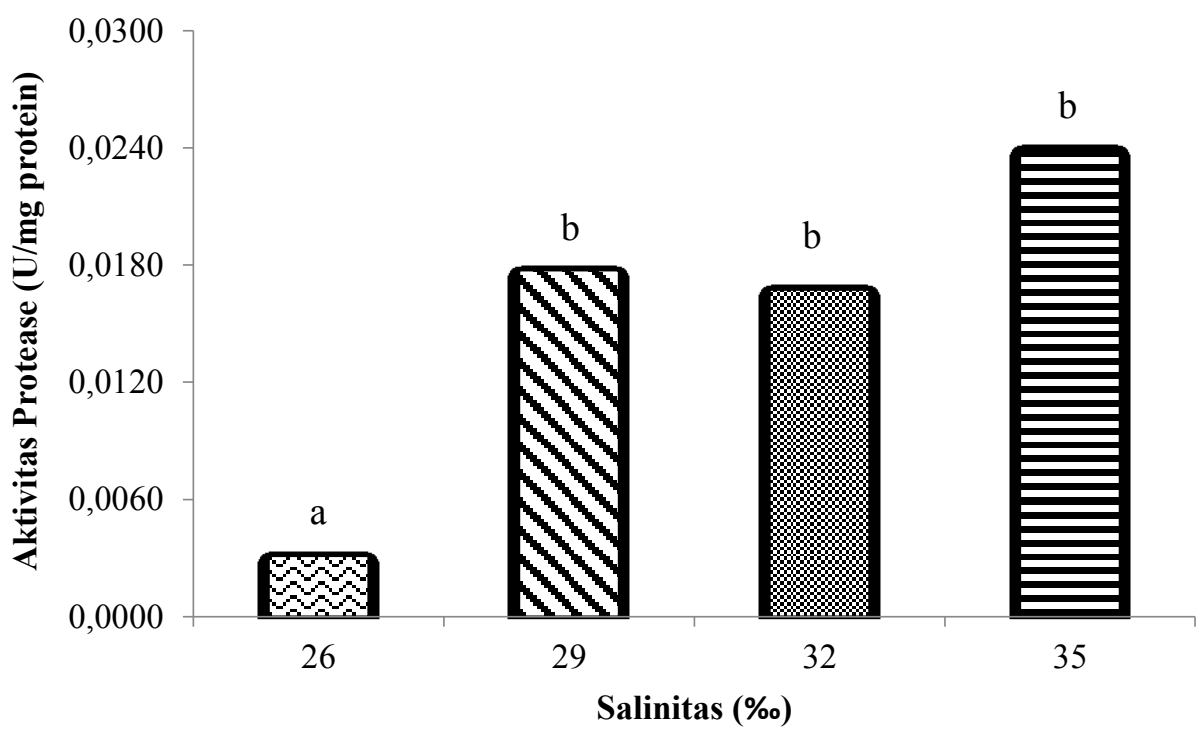

Gambar 2. Aktivitas protease juvenil abalone H. asinina pada salinitas media berbeda. ${ }^{\mathrm{a}, \mathrm{b}}$ superscript yang berbeda menunjukkan perbedaan signifikan pada taraf $\alpha=0,05$.

\section{PEMBAHASAN}

Secara garis besar ada tiga jenis enzim yang berperan dalam pencernaan pakan, termasuk amilase protease. Protease merupakan enzim yang menghidrolisis ikatan peptida pada rantai polipeptida hingga menjadi asam amino dan amilase menghidrolisis karbohidrat. Aktivitas enzim yang diukur dikhususkan pada kedua enzim ini karena abalon merupakan organisme akuatik herbivora yang sumber energi terutama diperoleh dari karbohidrat dan protein. Picos-Garcia et al. (2000) menyatakan bahwa energi metabolisme sebagian besar gastropoda termasuk abalone berasal dari pemanfaatan karbohidrat pakan. Di alam maupun pada kegiatan budidaya, abalone terutama diberi pakan alami berupa makroalga yang memiliki kandungan karbohidrat terbesar, kemudian disusul protein dan setelah itu lemak. Britz et al. (1996) melakukan investigasi terhadap aktivitas enzim pencernaan abalon jenis $H$. midae dan menemukan bahwa aktivitas protease meningkat secara signifikan selama proses pencernaan, sedangkan aktivitas amilase dipertahankan pada level konstan. Sementara itu, lipase menunjukkan aktivitas yang rendah, mengindikasikan kemampuan abalone yang rendah dalam mencerna lemak.

Aktivitas enzim pencernaan karbohidrase (selulase, lysozyme), protease (trypsin, aminopeptidase dan protease non spesifik) serta lipase non spesifik pada abalon $H$. rufescens paling tinggi ditemukan pada kelenjar pencernaan, dan aktivitas selulase, lysozyme, chymotrypsin serta protease tertinggi ditemukan pada kelenjar pencernaan dan perut (GarciaEsquivel dan Felbeck, 2006). Sementara itu, lipase dan amino peptidase ditemukan paling tinggi aktivitasnya pada mulut dan usus. Aktivitas protease juga diobservasi oleh Picos-Garcia et al. (2000) pada $H$. Fulgens dan diperoleh bahwa kandungan protein terlarut dan aktivitas protease di hepatopankreas lebih tinggi dari pada di organ viscera.

Hasil penelitian menunjukkan bahwa enzim pencernaan amilase semakin meningkat aktivitasnya dengan menurunnya salinitas. Dominasi aktivitas amilase pada salinitas yang lebih rendah 
memberikan dugaan bahwa bahwa pada salinitas tersebut terjadi pemanfaatan karbohidrat yang lebih tinggi. Britz et al. (1996) menyatakan bahwa aktivitas amilase abalon $H$. midae cenderung dipertahan pada level konstan baik saat diberikan pakan buatan maupun pakan alami pada kondisi kualitas air yang sama. Wang et al. (2013) menyatakan bahwa aktivitas amilase biota akuatik yang cenderung menjadi lebih tinggi tinggi pada media salinitas rendah (hipoosmotik) diduga merupakan respon untuk memperoleh sebanyak-banyaknya energi dari makanan yang diperlukan untuk melakukan regulasi hiperosmotik.

Regulasi osmotik atau osmoregulasi dilakukan untuk menjaga kemantapan milieu interiur dengan cara mengatur keseimbangan konsentrasi osmotik antara cairan intrasel dan ekstrasel untuk mencapai kondisi homeostatis dan prosesnya memerlukan energi (Anggoro, 1992). Berdasarkan Saridu et al. (2017), abalon $H$. asinina yang dipelihara pada salinitas rendah berada pada kondisi hiperosmotik terhadap media dan tingkat kerja osmotik (TKO) berada pada nilai yang lebih tinggi. Semakin besar nilai TKO, maka semakin besar pula energi yang dibutuhkan untuk mencapai keseimbangan osmotik. Boeuf dan Payan (2001) menyatakan, diperlukan 20-50\% dari total pembelanjaan energi untuk menjaga keseimbangan osmotik. Energi tersebut diperoleh dari makanan, dan abalon merupakan hewan herbivora dengan kecenderungan pemanfaatan karbohidrat pakan yang lebih besar dalam perolehan energi metabolisme dibandingkan protein (Faturrahman et al., 2015).

Sejalan dengan hasil penelitian ini, beberapa spesies akuatik lainnya menunjukkan peningkatan aktivitas amilase yang lebih tinggi pada salinitas rendah. Huang et al. (2016) melaporkan eskpresi mRNA $\alpha$-amilase kerang mutiara
Pinctada fucata yang secara signifikan lebih tinggi pada salinitas rendah (15\%o, $21 \%$ dan 27\%o) dibandingkan pada salinitas tinggi (33\% dan 39\%o). Wang et al. (2013) melaporkan aktivitas amilase yang jauh lebih tinggi pada kepiting Eriocherir sinensis ketika kepiting dipelihara pada air tawar atau pada media yang hipoosmotik.

Berbeda dengan amilase, aktivitas protease juvenil $H$. asinina diperoleh lebih tinggi pada salinitas yang lebih tinggi. Aktivitas protease pada salinitas 26\%o sangat rendah dan berbeda nyata dengan perlakuan lainnya. Rendahnya aktivitas protease dapat menyebabkan rendahnya pertumbuhan bobot tubuh karena protein terutama digunakan untuk penambahan biomassa. Berdasarkan Faturrahman et al. (2015), peningkatan pertumbuhan abalon terjadi melalui beberapa mekanisme yang salah satunya adalah peningkatan aktivitas enzim di saluran pencernaan. Meskipun terjadi peningkatan aktivitas enzim amilase pada salinitas rendah, energi yang diperoleh dari karbohidrat banyak dikeluarkan untuk kerja osmotik. Implikasi dari rendahnya aktivitas protease adalah rendahnya kecernaan protein pakan sehingga dapat mempengaruhi pertumbuhan. Wahyu et al. (2014) melaporkan bahwa juvenil abalon yang dipelihara pada salinitas rendah memiliki kecernaan yang rendah pula. Dinyatakan juga bahwa berkurangnya ktivitas enzim pada salinitas yang lebih tinggi mengindikasikan bahwa kapasitas pencernaan hewan yang diaklimasi pada salinitas tersebut semakin melemah (Wang et al., 2013). Selanjutnya, berdasarkan Saridu et al. (2017) juvenil abalon yang dipelihara pada salinitas di bawah 29\%o mengalami penurunan pertumbuhan.

Moutou et al. (2004) menyatakan bahwa pengaruh salinitas terhadap aktivitas protease terkait dengan aktivasi zymogen. Jobling (1995) melaporkan, protease disintesis sebagai zymogen yang 
tidak aktif di dalam sel pankreas dan aktivasinya dibantu oleh proteolitik spesifik dan salinitas dapat mempengaruhi pengaktifan zymogen yang terdapat di luar dinding sel pada usus. Pengaruh salinitas terhadap aktivitas enzim terkait dengan regulasi osmotik organisme akuatik dimana perubahan salinitas dapat mempengaruhi laju minum (Usher et al., 1988). Peristiwa ini menyebabkan terjadinya perubahan salinitas di dalam usus dan pada akhirnya mempengaruhi aktivitas enzim. Perubahan salinitas media menyebabkan terjadinya reorganisasi metabolisme akibat penurunan atau peningkatan pengambilan ion dari media eksternal (Wang et al., 2013).

Hasil pengukuran aktivitas enzim amilase dan protease pada studi ini menunjukkan bahwa aktivitas amilase lebih tinggi daripada aktivitas protease pada semua perlakuan. Tingginya aktivitas amilase terkait dengan pakan yang diberikan yaitu makroalga yang kandungan karbohidratnya lebih tinggi dari pada kandungan ptotein. Hal ini merefleksikan abalon sebagai hewan herbivora yang lebih memanfaatkan karbohidrat pakan. Hal ini sesuai dengan pernyataan (Johnston et al., 2005) bahwa aktivitas enzim secara umum konsisten dengan material yang dicerna. Abalon yang diberi pakan diatom menunjukkan amilase yang lebih tinggi daripada aktivitas protease dengan rasio aktivitas amilase dan protease sebesar 4,0, mengindikasikan abalon sebagai hewan herbivora (Knauer et al., 1996).

Meskipun herbivora, Britz et al. (1996) melaporkan bahwa abalon dapat mencerna pakan buatan yang komposisi nutrisinya lebih tinggi daripada yang terkandung dalam makanan alaminya, sehingga aktivitas protease dapat meningkat sebagai respon terhadap tingginya kandungan protein pakan. Garcia-Carreno et al. (2003) menyatakan bahwa enzim pencernaan abalon secara anatomi dan biokimia disesuaikan dengan jenis makanan yang dikonsumsi, dimana enzim pencernaan digunakan untuk memecah struktur polisakarida dan menghidrolisis protein pada makroalga yang menjadi makanan abalon. Beberapa studi melaporkan bahwa rasio aktivitas total proteinase dan total amilase pada hewan omnivora dan herbivora lebih rendah daripada hewan karbivora (Tsuzuki et al., 2007; Hassanatabar et al., 2013). Nikapitiya et al. (2009) melaporkan ekspresi gen $\alpha$-amilase yang lebih tinggi di hepatopankreas H. discus discus, mengindikasikan bahwa gen ini lebih signifikan untuk proses pencernaan abalon dan memiliki peran penting dalam degradasi zat tepung dan glikogen dalam tumbuhan.

\section{KESIMPULAN}

Penelitian ini memperoleh bahwa salinitas mempengaruhi aktivitas amilase dan protease juvenil abalone $H$. asinina. Berdasarkan hasil penelitian, $H$. asinina sebaiknya dipelihara pada salinitas $>29 \%$ karena aktivitas protease yang sangat rendah dapat menurunkan kecernaan protein sehingga menghambat pertumbuhan.

\section{UCAPAN TERIMA KASIH}

Penulis mengucapkan terima kasih kepada Direktorat Pendidikan Tinggi atas pendanaan dalam melaksanakan penelitian ini.

\section{REFERENSI}

Anggoro, S. 1992. Efek Osmotik Berbagai Tingkat Salinitas Media Terhadap Daya Tetas Telur dan Vitalitas Larva Udang Windu, Penaeus monodon Fabricius. Disertasi, Fak. Pascasarjanan, IPB, Bogor. 127 halaman.

Anggoro, S. 2000. Pola Regulasi Osmotik dan Kerja Enzim Na-KATPase Udang Windu (Penaeus monodon Fabr.) pada Berbagai Fase 
Media Akuatika : Jurnal Ilmiah Jurusan Budidaya Perairan. 2021. 6(3): 135-143.

Molting. Aquaculture Indonesia, 1: 15-20.

Bhatnagar, A. and P. Devi. 2013. Water Quality Guidelines for The Management of Pond Fish Culture. International Journal of Environmental Sciences, 3: 19802009.

Boeuf, G. and P. Payan. 2001. How Should Salinity Influence Fish Growth. Comp. Biochem. Physiol., Part CPharmacol. Toxicol. 130, 411423.

Britz, P. J., T. Hecht and J. Knauer. 1996. Gastric Evacuation Time and Digestive Enzyme Activity in Abalone Haliotis midae Fed a Formulated Diet. S. Afr. J. Mar. Sci., 17: 297-303.

Burke, C.M., J.O. Harris, S.M. Hindrum, S.J. Edwards and G.B. Maguire, G.B. 2001. Environmental Requirements of Abalone. Tasmania Aquaculture and Fisheries Institute, Tasmania, 150p.

Chaitanawisnu, N., S. Nunim and W. Santhaweesuk, W. 2012. The Combined Effect of Temperature and Salinity on Survival of Larvae and Juveniles of Tropical Abalone Haliotis asinina Under Laboratory Condition. Journal of research in Biology, 2: 572-579.

Cheng, W., S.P. Yeh, C.S. Wang and J.C. Chen. 2002. Osmotic and Ionic change in Taiwan abalone Haliotis diversicolor supertexta at different salinity. Aquaculture 203: 394-357.

Faturrahman, Rohyati, I. S., \& Sukiman, dan. (2015). Improved of Growth Rate of Abalone Haliotis Asinine Fed Pudding Probiotic-enriched Protein. Procedia Environmental Sciences, 23(Ictcred 2014), 315-322. https://doi.org/10.1016/j.proenv.201 5.01 .046

Garcia-Carreno, F.L., M.A. Navarrete del Toto and E. Serviere-Zaragoza.
2003. Digestive Enzymes in Juvenile Green Abalone, Haliotis fulgens, Fed Natural Food. Comparative Biochemistry and Physiology Part B, 134: 143-150.

Garcia-Esquivel, Z. and H. Felbeck. 2006. Activity of Digestive Enzymes Along the Gut of Juvenile Red Abalone, Haliotis rufescens, Fed Natural and Balanced Diets. Aquaculture, 261: 615-625.

Hassanatabar, F., H. Ouraji, A. Esmaeili and Babaei. 2013. Study of the Activities of Digestive Enzymes, Amylase and Alkaline Phosphatase, in Kutum Larvae, Rutilusfrisiikutum Fed Artemia Nauplii. World Journal of Fish and Marine Sciences 5(3): 226-270.

Huang, G., Y. Guo, L. Li, S. Fan, Z. Yu and D. Yu. 2016. Genomic Structure of the $\alpha$-amilase Gene in the Pearl Oyster Pinctada fuata and Its Expression in Response to Salinity and Food Concentration. Gene, 587: 98-105.

Jobling, M. 1993. Bioenergetics: Feed Intake and Energy Partitioning. Fish Ecophysiology, 289:263-276.

Johnston, D., N. Moltschaniwskyj and J. Wells. 2005. Development of the Radula and Digestive System of Juvenile Blacklip Abalone (Haliotis rubra): Potential Factors Responsible for Variable Weaning Success on Artificial Diets. Aquaculture, 250: 341-355.

Knauer, J., P.J. Britz and T. Hecht. 1996. Comparative Growth Performance and Digestive Enzyme Activity of Juvenile South African Abalone, Haliotis midae, Fed on Diatoms and A Practical Diet. Aquaculture, 140: 75-85.

Magnussen, A. B., A.K. Imsland and A. Foss. 2008. Interactive Effects of Different Temperatures and Salinities on Growth, Feed 
Media Akuatika : Jurnal Ilmiah Jurusan Budidaya Perairan. 2021. 6(3): 135-143.

Conversion Efficiency, and Blood Physiology in Juvenile Spotted Wolffish, Anarhichas minor Olafsen. J. World Aquaculture Soc., 39: 804811.

Moustakas, C.T., W.O. Watanabe and K.A. Copeland. 2004. Combined Effects Of Photoperiod and Salinity on Growth, Survival, and Osmoregulatory Ability of Larval Southern Founder Paralichthys lethostigma. Aquaculture, 229: 159179.

Moutou, K.A., Panagiotaki, P. and Mamuris, Z., 2004. Effects of Salinity on Digestive Activity in The Euryhaline Sparid Sparus aurata L.: A Preliminary Study. Aquac. Res., 35, 912-914.

Nikapitiya, C., C. Oh, I. Whang, C.G. Kim, Y.H. Lee, S.J. Kim and J. Lee. 2009. Molecular Characterization, Gene Expretion Analysis and Biochemical Properties of $\alpha$-amilase from the Disk Abalone, Haliotis discus discus. Comparative Biochemistry and Physiology, Part B, 152: 271-281.

Picos-Garcia, C., F.L. Garcia-Carreno and E. Serviere-Zaragoza. 2000. Digestive Protease in Juvenile Mexican Green Abalone, Haliotis fulgens. Aquaculture, 181: 157-170.

Romano, N. 2010. Investigating the Survival, Growth, and Osmoregulatory Responses of Blue Swimmer Crab, Portonus pelagicus Early Juveniles to Salinity and Ammonia Challange. $\mathrm{PhD}$ thesis. James Cook University, Australia, $184 p$.

Saridu, S. A., Anggoro, S., \& Suprijanto, J. (2017). Prosiding Seminar Nasional Hasil-Hasil Penelitian Perikanan dan Kelautan ke-VI Fakultas Perikanan dan Ilmu Kelautan - Pusat Kajian Mitigasi Bencana dan Rehabilitasi Pesisir,
Undip 1. Prosiding Seminar Nasional Hasil-Hasil Penelitian Perikanan Dan Kelautan Ke-VI Fakultas Perikanan Dan Ilmu Kelautan - Pusat Kajian Mitigasi Bencana Dan Rehabilitasi Pesisir, Undip 1, 716-727. http://eprints.undip.ac.id/54833/

Tsuzuki, M.Y., J.K. Sugai, J.C. Maciel, C.J. Francisco and V.R Cerquiera. 2007. Survival, Growth, and Digestive Enzyme Activity of Juvenils of the Fat Snook (Centropomus parallelus) Reared at Different Salinities. Aquaculture, 271: 319-325.

Usher, M.L., C. Talbot and F.B. Eddy. 1988. Drinking in Atlantic Salmon Molts Transferred to Seawater and The Relationship Between Drinking and Feeding. Aquaculture, 73: 237246.

Wahyu, S. Anggoro, J. Suprijanto. 2014. Pengaruh Salinitas Berbeda terhadap Tingkat Kecernaan dan Penyerapan Pakan (Gracillaria verucosa) sebagai Energi Pertumbuhan Abalon. Prosiding Seminar Nasional Tahunan IX Hang Tuah IX.

Wang, R., P. Zhuang, G. Feng, L. Zhang, $X$. Huang, F. Zhao and Y. Wang. 2013. The Response of Digestive Enzymes Activity in the Mature Chinese Mitten Crab, Eriocheir sinensis (Decapoda: Brachyura), to Gradual Increase of Salinity. Scientia Marina, 72(2): 323-329.

Xizhu, Y. 2004. A Study on The Bioenergetic of Haliotis diversicolor aquatilis. Ph.D Thesis, College of Oceanography and Environmental Sciences of Xiamen University. China.

Zweig, R.D., 1999. Source Water Quality for Aquaculture, A Guide for Assessment. International Bank for Reconstruction and Development, Washington. 